\title{
The Role of Advanced Technology in Agricultural Innovation
}

ISSN: 2637-7659

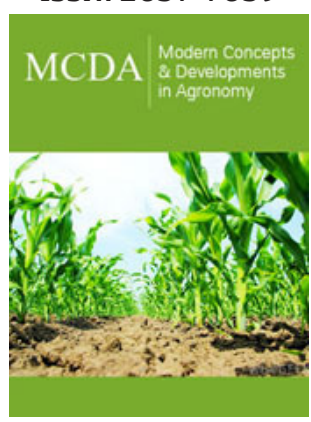

*Corresponding author: Ikpe-etim Nathan OBOMUFOK , Hangzhou

Submission: 此 March 08, 2019

Published: 漹 March 18, 2019

Volume 34 - Issue 1

How to cite this article: Yu Rongjian, Ikpe-etim Nathan OBOMUFOK, Nazar K. The Role of Advanced Technology in Agricultural Innovation. Mod Concep Dev Agrono.4(1). MCDA.000576.2019.

DOI: 10.31031/MCDA.2019.04.000576

Copyright@ Ikpe-etim Obomufok Nathan, This article is distributed under the terms of the Creative Commons Attribution 4.0 International License, which permits unrestricted use and redistribution provided that the original author and source are credited.

\author{
Yu Rongjian ${ }^{1}$, Ikpe-etim Nathan OBOMUFOK ${ }^{1 *}$ and Kashif Nazar Khan \\ ${ }^{1}$ Zhejiang Gongshang University, Hangzhou \\ ${ }^{2}$ COMSATS institute of information technology, Islamabad
}

\begin{abstract}
In many countries of the world, technology plays a leading role in the transformation of businesses. This study adopts a survey of literature in agriculture sector and gives certain recommendations which are evolved after descriptive analysis of literature. After systematic review of literature in Chinese, Pakistani and Nigerian context, our paper describes that agricultural policy and agricultural funding are connected to many problems in agriculture field and needs social and strategic steps to be taken particularly in Nigeria. The way observed by the study includes increased budgetary allocation for agriculture, adding a line of technological development, and expansion to social responsiveness in Agricultural Motor Mechanics and Tractors Operators Training Centres (AMMOTRAC). Our study has theoretical implications in social, technology and business research and has practical implication regarding liaison and funding cooperation among the Research and Development (R\&D) Agencies.
\end{abstract}

\section{Introduction}

Food is the most desirable need among basic necessities of human being. This underscores the importance of food security in human existence. Plant and animal derivatives which serve as the primary sources of food are products of agriculture. Agricultural sector spans across food cultivation, forestry, poultry, beekeeping, fish farming, and piggery. In line with the World Bank development report (2012), 2/3 development in agricultural sector is input from developing countries. In early 1960s and 1970s, China vigorously pursued technology acquisition which contributed into making China a superpower today. China focuses on technological advancement to create more opportunities for the world. As a result, her level of technological advancement makes China the one of the largest economies of the world. Agriculture is one of the most critical sectors of the economy which contributed to China's phenomenal growth as the second largest global economy. It provides 12 percent of the total GDP of China and employs more than 300 million people, representing about 50 percent of the entire workforce thereby impacting positively on national development in the country. Comparatively, China is believed to provide the highest output in agriculture and further produces 28 percent of the world's cereal and grains, 22 percent of the world's meat and 50 percent of the world's vegetables. Furthermore, China is the world's largest producer of pork, wheat, rice, tea, cotton, and fish. China's agricultural sector has attained food security for it is over 1.3 billion people and jobs for 50 percent of its workforce thereby contributing substantially to her national development aspirations. Agriculture in Nigeria equally contributes its quota to the Nigerian economy and national development. The sector provides means of livelihood to about 90 percent of the population in the rural areas and contributes about 25 percent of the total GDP of Nigeria. Similarly, the agricultural sector employs about 70 percent of the labor force in the country. Despite these relative achievements in the agricultural sector, most of the vast arable lands in Nigeria are uncultivated. This implies that the sector has substantial untapped agriculture potentials which could further enhance national growth and development in Nigeria. Recognizing the contributions of agriculture to the economy, the governments at Federal and State levels in Nigeria have made concerted efforts to increase agricultural yields. Some of these efforts include the Green Revolution, Operation Feed the Nation, 7-Point Agenda and more recently the Transformation Agenda which are designed to enhance national development in Nigeria. Notwithstanding these 
programmes, Nigeria is yet to achieve food security for its teeming population.

In research, there are different methods used in collecting data, all of which fall into two categories, i.e., primary and secondary data [1]. Data for the study were obtained from both primary and secondary sources. Primary sources of data involved one on one interview with experts in the field of study, Non-Governmental Organisations (NGOs), Ministries, Departments and Agencies (MDAs) amongst others. Primary sources of data in this study would involve Federal Ministry of Agricultural and Rural Development (FMARD), Central Bank of Nigeria (CBN), Bank of Agriculture (BOA), African Development Bank (AfDB) and FADAMA Offices by getting the views of respondents through interviews on various questions relating to agriculture through technology in Nigeria. On the other hand, secondary sources are data collected from government publications websites, books, journal articles, internal records, published and unpublished, newspapers and magazines. These data are collected by a party when the study needs to fill other gaps.

\section{Literature Review}

The literature review looks at several authors such as [2-5] who have used their analysis in technological innovation index and explained which factor the best decision variable for the enterprise is. In summary, the literature reviewed highlighted the importance of technology. However, none of the works focused extensively on the utilization of technology for enhancing agriculture production. All these create the gap for further study by focusing on identifying the problems of agriculture in Nigeria. It is this gap in the literature that this study "the Role of Advanced Technology in Agriculture: Nigeria and China as A Case Study" seeks to fill. In doing this, it is necessary to establish the relationship between technology and agriculture using social explanations by the firms. This becomes the social responsibility of firms take account of wants of the community [6].

\section{Adaptation of technological innovation for enhancing agricultural development in China}

China is vigorously pursuing technology by considering social element of businesses which is making it a superpower today. There is a drastic increase in implementation of e-commerce in many business industries of China in service delivery [7]. It seems that following an increase in agriculture production, the Government of China established the DuPont Research \& Development and Centre Co., Ltd (CTC) in 2005 which engages in the research and development of new technological devices for improving agricultural production (Figure 1\&2). The home to the DuPont CTC is located in Shanghai, China. This site is the leading center for research, product development, customer support, and materials testing in China. The China DuPont is promoting corn farming mechanization and hybrid seed technology to improve crop yields. (EI DuPont, 2013). Nigeria is yet to benefit significantly in technology toward enhancing agricultural production.

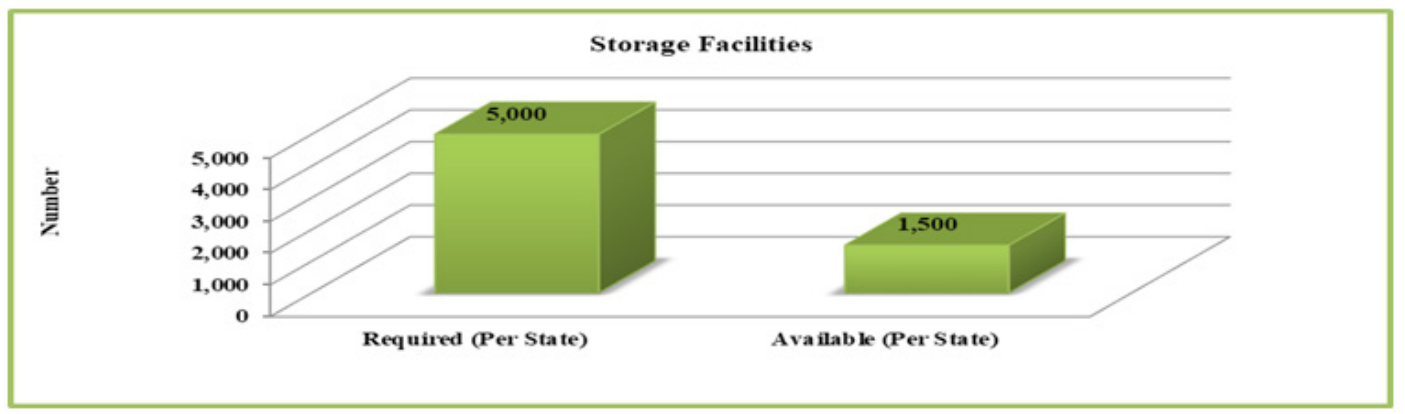

Figure 1: Comparative analysis of required and available storage facilities in Nigeria.

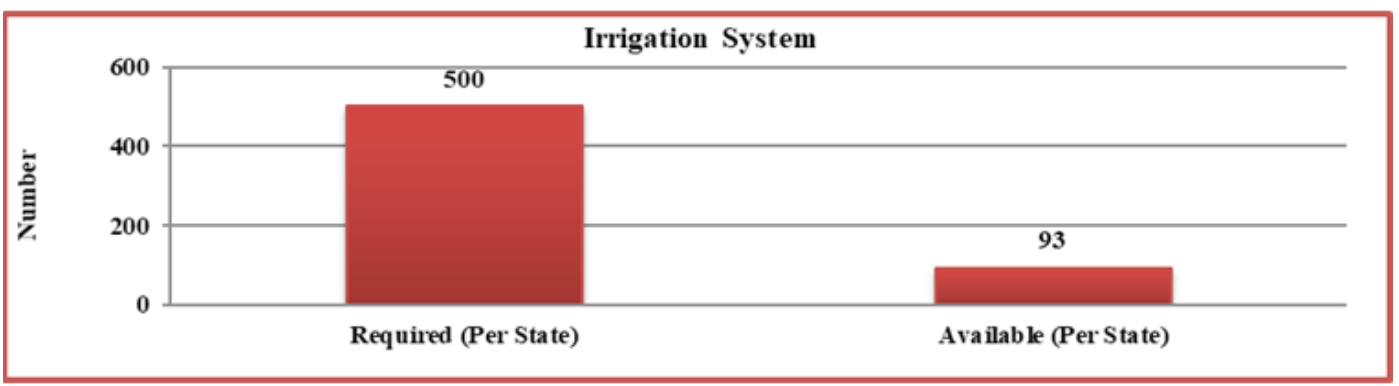

Figure 2: Comparative analysis of required and available farm infrastructure on irrigational system of farming in Nigeria.

\section{Differences in technological innovation in agriculture}

Pakistan is a developing country which is rich and almost self-dependent in agriculture sector. On the other hand, Nigera is African country which is not totally independent in agri production and promulgation of internal harvestings. China has for long been introducing various forms of technological innovations towards enhancing agricultural development to better the lives and wellbeing of her citizens. For instance, since the $1^{\text {st }}$ Century BC, China had invented the hydraulic-powered trip hammer to make farming easy for farmers in the country. The government of China has further established a science and technology cooperation 
relationship with Canada since 1980s towards technological innovation for agricultural improvement in China. For instance, the Agriculture and Agri-Food Canada (AAFC) has hosted numerous Chinese scientists and students in the Canadian research centres and exchanged knowledge and information through seminars, workshops, joint projects and other forms of collaboration. Every year, the AAFC 19 research centers host scientists and graduate students from China. Between 2006 and 2014, the institution hosted more than 200 Ph.D. students and over 100 visiting scientists.

These exchanges advance work of importance to Canada and China as evidenced by the fact that since 2006, AAFC scientists have co-authored more than 1,000 scientific publications with Chinese scientists. Currently, China Agricultural University, Beijing, is showing more flexibility in agriculture engagements than those of conventional actors from Western countries, which usually have a 'rigid logic framework' for the design and implementation of aid projects. These technologies adopted in China have significantly impacted on agriculture with dire consequences on the lives of the citizens. Strengthening the framework, we have adopted the cross cultural approach not only in technological perspective but also corporate and social responsive [8] perspective because now firms and agencies have to be transparent in the earnings [9] and corporate relations. On the other hand, Nigeria is not adequately advance in her technology towards enhancing agricultural development. Some of the reasons for poor technology in Nigeria are brain drain, poor educational system and lack of funding of the education system. For instance, the FGN budgetary allocation to the educational sector of 7\% percent out of the $\$ 8.6$ trillion in the 2018 is lower compared to the $7.4 \%$ percent of the $\$ 7.4$ trillion in 2017 budget [10].

\section{How the differences in technology affect agriculture in Nigeria?}

The inadequacy of explicit agricultural technology for several decades has not only complicated efforts to understand the relationship between agricultural technology and to design ways to make agricultural technology more effectively but has increase the level of poverty and food security in Nigeria. Even after recovering from the recent recession, the FGN has not made concerted efforts to impact on the technology for enhancing agricultural development. According to the World Bank (WB), unemployment and poverty rates increased in Nigeria despite an exit from recession in 2017. The rate of unemployment and underemployment increased in 2017 and poverty is also increased slightly. The 2018 population of Nigeria is estimated at 180 million people; however, $67 \%$ percent of the population lives below poverty line [11]. The level of availability of farming infrastructure is very low in Nigeria. This discourages harvest and post-harvest activities in the farming. In most states, the amount of funding put into the provision of farming infrastructure such as road, irrigation, and market by the government is very low. This is as a result of poor internally generated revenue from those states. Also, farmers do not have adequate storage facilities. Based on this, more than 35 percent of farm produce are destroyed before getting to the markets. According to Dandam [12], without these farm infrastructures, there can never be a meaningful increase in the contribution of technology to agriculture in Nigeria. As such, even if adequate technological infrastructures were provided without formulating a maintenance system for them, it would not encourage agriculture in Nigeria.

\section{Some problems of agricultural development and how they affect Nigeria}

Agricultural policy: The national agricultural policy thrust has been on sustenance basis. Specific concept of subsistence agricultural production was not captured in the past agricultural policies and schemes. The development of agriculture needs a dynamic and sustainable policy to accomplish national food security objections. Asoegwu [13] emphasized that inconsistency and absence of appropriate technology associated with previous agricultural policies affect its effectiveness. The absence of concrete policy direction on the procurement of appropriate tractors and other agricultural implementation has affected agriculture negatively in Nigeria. Also, the inappropriate macroeconomic policy has also affected the provision of enabling an environment for agricultural growth in equilibrium with other sectors. The situation worsened by inconsistencies in monetary and fiscal policies which led to the dependence of agriculture on imported implements with attendant adverse effect on development. Ineffective agriculture policy is, therefore, an impediment to the improvement of agriculture in Nigeria.

Infrastructure: The state of technological infrastructure is essential in agriculture through the National FADAMA Project (NFP) for enhanced agricultural production in Nigeria. Infrastructure is pertinent to the growth of agriculture in areas such as agro-allied, research extension, transportation, and services among others. Its provision is what defines the input and output of agricultural productivity. With regards to NFP, the infrastructure required to drive agriculture include tractors, irrigation system, storage facility and roads among others. In some states, however, these infrastructures are inadequate to cater to the size of production in the NFP. For instance, in 2016, the FMARD stated that with the current focus of the NFP, the required irrigation system per state is put at an average of 500 projects, but the availability is put at an average of 93 projects. Similarly, the required number of storage facilities per state is at an average of 5,000, but the availability is less than 1,500. Figure 2 is a comparative analysis of required and available farm infrastructure including an irrigation system, road, storage facilities, and market. This level of farming infrastructure is due to low investment in the provision of farming infrastructure in most of the states (Figure 3\&4). According to Usman [14] many states do not have the financial capability to provide the required technological infrastructure for NFP. Based on this, they are dependent on allocation from the FGN which most times is not enough to execute the NFP. He affirmed that the provision of farming infrastructure is a long-term, financially demanding action of the states government and FGN $[15,16]$. However, the lack of plans for the provision of the technological infrastructure by stakeholders does not encourage the contributions of agriculture through NFP for enhanced agricultural growth in Nigeria. Therefore, technological infrastructure is a significant factor for enhanced agricultural growth and development in Nigeria. 


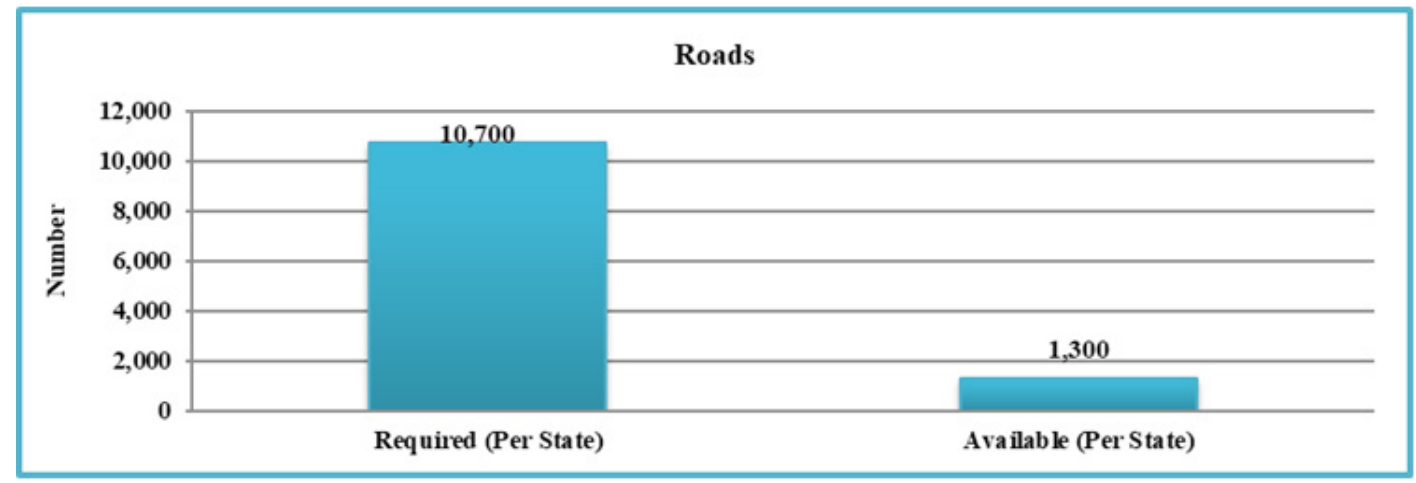

Figure 2: Comparative analysis of required and available road network availability amongst farm infrastructure in Nigeria.

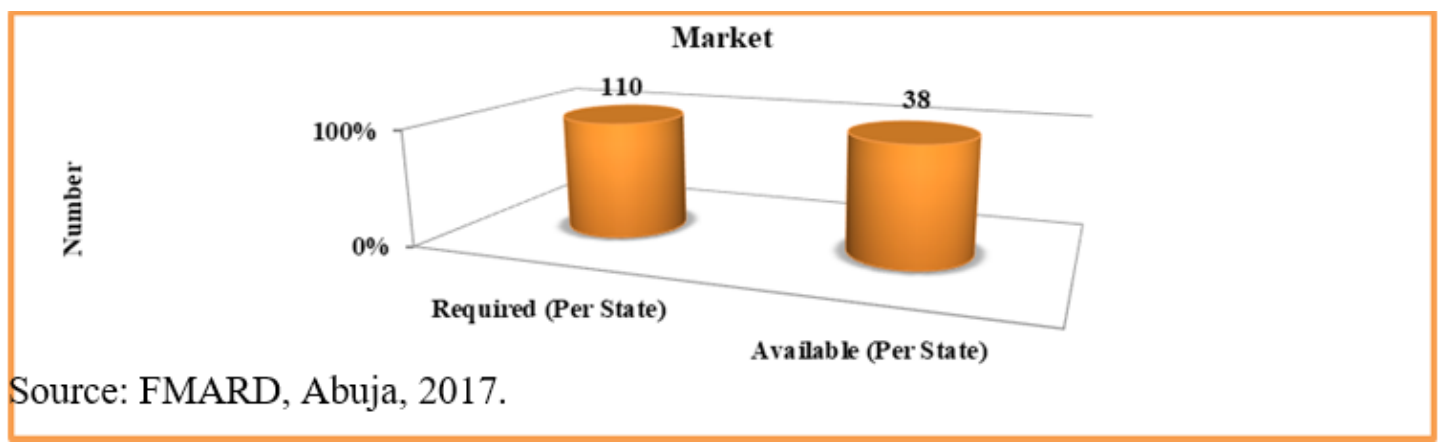

Figure 2: Comparative analysis of required and available market for agricultural production in Nigeria.

\section{Conclusion}

The FGN over the years has made tremendous efforts to improve technology in Nigeria towards enhancing agriculture. However, these efforts prove abortive as the agriculture in Nigeria is faced with problems such as weak agricultural policy, poor technological infrastructure and low agricultural funding. Other problems facing the agriculture in Nigeria include stringent conditions for private sector participation in agriculture, difficulty in accessing land for agriculture, poor linkage among agricultural research institutes, land tenure system in Nigeria as well as R\&D. Despite these problems, some of the ways forward identified by this study include increased budgetary allocation for agriculture, as well as the development of technological base and expansion of AMMOTRAC, would boost agriculture in Nigeria. The study further identified that adequate funding and liaison among the R\&D Agencies, reactivation and reorganization of NALDA.

\section{Recommendations}

The FGN could further strengthen relationship with other countries to adopt the technology used in enhancing agricultural development with social considerations. The government of China collaborated with Canadian government to educate their students more on agricultural technological. This has helped in strengthening China's agricultural sector thereby improving on the wellbeing of the populace despite China's over 1 billion population. The FGN could further adopt this measure and spend more on education to train some students overseas on agricultural technology as a panacea to improving agriculture in Nigeria and Pakistan. This would increase the budgetary allocation of Nigeria and thus reduce poverty minimum by next decade.

\section{References}

1. Douglas M (2015) Sources of data.

2. Chen Wu-Jun et al. (2010) Appraising enterprise technology innovation project. University of Toyama, Japan.

3. Gao Q Zhang C (2011) Analysis of innovation capability of agricultural hi-technology industries in China. Journal of Innovation: Management policy and practice 3(3): 278-290.

4. Wang Z (2007) Technological innovation capacity index system. Economic conference, Wuhan University of Science and Technology, Hubei Wuhan, China.

5. Petit M (2015) Sustainable agricultural development: Challenges and approaches in southern and eastern mediterranean countries. Springer.

6. Hao Y, Farooq Q Zhang Y (2018) Unattended social wants and corporate social responsibility of leading firms: Relationship of intrinsic motivation of volunteering in proposed welfare programs and employee attributes. Corporate Social Responsibility and Environmental Management 25(6): 1029-1038.

7. Farooq Q Fu P, Hao Y, Jonathan T, Zhang Y (2019) A review of management and importance of e-commerce implementation in service delivery of private express enterprises of china. SAGE Open 9(1).

8. Farooq Q, Hao Y, Liu X (2019) Understanding corporate social responsibility with cross-cultural difference: A Deeper Look at Religiosity. Corporate Social Responsibility and Environmental Management.

9. Zhang L, Farooq Q, Zhang Y, Liu X, Hao Y (2019) Fair value and mispricing: How domestic earnings transparency of listed firms leads to global financial stability. European Journal of International Management.

10. Adedigba A (2017) 2018 budget: Buhari allocates 7\% to education. 
11. Vanguard Newspaper (2018) 67\% Nigerians live below poverty linepresidential aide.

12. Dandam GG (2017) Plateau state project coordinator, National Fadama Project, speech on "Agriculture and National development in Nigeria: An Appraisal of the National Fadama Project.

13. Asoegwu SN, Asoegwu AO (2007) An overview of agricultural mechanisation and its environmental management in Nigeria International Commission of Agricultural Engineering: CIGR E-Journal
$9(6): 5$.

14. Usman SK (2017) Agriculture and national development in Nigeria: An appraisal of the National FADAMA project. p.50.

15. Company Overview of Dupont (China) Research \& Development and Management Co Ltd.

16. FAO (2015) How to feed the world in 2050. p. 5.

For possible submissions Click below: 